\title{
Effects of Enrichment Planting with Five Native Species and Different Plantation Treatments on Seedling Growth Characteristics at Logged-over Forest in Lao PDR
}

\author{
Chanhsamone Phongoudome ${ }^{1}$, Silavanh Sawathvong ${ }^{2}$, Su Young $\mathbf{W o o}^{3}$, \\ Wai Mun $\mathrm{Ho}^{4}$ and Yeong Dae Park ${ }^{5 *}$ \\ ${ }^{l}$ Forest Research Centre, National Agriculture and Forestry Research Institute, \\ Ministry of Agriculture and Forestry, Vientiane, Lao PDR P.O. Box: 7174 \\ ${ }^{2}$ Department of Forestry, Ministry of Agriculture and Forestry, Vientiane, Lao PDR P.O. Box: 7174 \\ ${ }^{3}$ Department of Environmental Horticulture, University of Seoul, Seoul 130-743, Korea \\ ${ }^{4}$ Forest Research Institute Malaysia, 52109 Kepong, Selangor, Malaysia \\ ${ }^{5}$ Research Institute for Agriculture and Life Sciences, Seoul National University, Seoul 151-921, Korea \\ (Received April 30, 2012; Revised June 26, 2012; Accepted June 27, 2012)

\section{라오스 개벌림에서 다섯가지 자생수종과 각기 다른 조림처리의 Enrichment Planting이 묘목의 생장특성에 미치는 효과}

\author{
찬사몬 폰고우돔 ${ }^{1}$ - 실라반 사와드봉 ${ }^{2}$ 우수영 ${ }^{3}$ - 와이문 호 $^{4} \cdot$ 박영대 $^{5 *}$ \\ 라오스 농림부 국립농림업 연구소 산림연구센터, 2라오스 농림부 임업국, \\ ${ }^{3}$ 서울시립대학교 환경원예학과, ${ }^{4}$ 말레이시아 산림연구소, ${ }^{5}$ 서울대학교 농업생명과학연구원 \\ (2012년 4월 30일 접수; 2012년 6월 26일 수정; 2012년 6월 27일 수락)
}

\begin{abstract}
Enrichment planting is commonly used for increasing the density of tree species in secondary forests and one of forest rehabilitation programs in Lao PDR. This study aimed to determine the performance of five native species in enrichment planting using different canopy opening treatments, and to examine the suitable species and silviculture techniques applicable to a logged-over forest in Lao PDR. Results of the study showed that only crown height had significant difference among species and planting treatments. The survival rate and crown diameter were significantly different by species, but not by planting treatments. However, root collar diameter (RCD) and height of seedlings showed significant differences among planting treatments. Among the study species, Hopea odorata and Dalbergia cochinchinensis showed significantly higher survival rate and height growth, indicating their suitability in enrichment planting for rehabilitation of forest in Lao PDR. The results also suggested that $2 \mathrm{~m}$ width line planting stimulated RCD growth, but wider line planting, such as gap planting, promoted height growth of seedlings.
\end{abstract}

Key words: Line and gap planting, Logged-over forest, Rehabilitation, Seedling growth, Survival rate

\section{INTRODUCTION}

Secondary forest constituted $63 \%$ of the total forest cover in Southeast Asia in 2005 (Kettle, 2010). Enrich- ment planting has been commonly used for restoring previously logged- over forests and increasing timber volume and economic value of secondary forests (Lamprecht, 1989; Kartawinata, 1994; Adjers et al.,

* Corresponding Author : Yeong Dae Park

(parkyd70@snu.ac.kr) 
1995; Paquette et al., 2006; Kettle, 2010). The general principle of enrichment planting is to improve the light environment condition around the planted seedlings by removing overtopping trees as canopy openings are critical for regeneration of many canopy tree species, and to reduce competition from surrounding undergrowth (Augspurger, 1984; Hartshorn, 1989; Appanah and Weinland, 1993; Denslow, 1995; Pena-Claros et al., 2002).

Enrichment planting by line and gap plantings are also practiced in tropical America, Africa and Asia Pacific on degraded early-sucessional and old fallow secondary forest (Appanah and Nair, 1999; Kobayshi et al., 1999; Oliveira, 2000; Pariona et al., 2003; Lamb et al., 2005; Park et al., 2005; Paquette et al., 2006; Inman et al., 2007). Enrichment planting can also be used in attempts to supplement natural regeneration, where it is judged to be insufficient (Appanah and Weinland, 1993). The method involves planting nursery-raised seedlings in cleared lines or in gaps that have either been created artificially or naturally (Wyatt-Smith, 1963). Line planting is now an established method (Lamb, 1969; Montagnini et al., 1997; Peña-Claros, 2002), but gap planting techniques in which clusters of seedlings are under-planted in artificially created gaps (Otsamo, 2000) or pre-existing gaps (Oliviera, 2000) are still at an experimental stage. The gap cluster planting approach is similar to "group-planting" as described by Anderson (1953) and or "nest-planting" (Anderson,
1951), in which seedlings of different species are planted together in a cluster.

In contrast to planting in regularly spaced lines, gap cluster planting has some resemblance to natural gap dynamics (Denslow, 1987; Kuuluvainen, 2002), which could be considered advantageous in restoration programs. Practical examples of enrichment plantation in tropical rainforests have been reported in many literature (Ådjers et al., 1995; Tuomela et al., 1996; Marod et al., 2004; Evans and Turnbull, 2007; Romell et al., 2008). However, drawing general conclusions regarding the effects of various treatments and the optimal conditions for enrichment planting is not straightforward due to the variability and dynamic nature of enrichment planting sites and the lack of knowledge regarding post planting site requirements in many species of the nursery-reared seedlings.

The factors considered important for the survival and early growth of under-planted non-pioneer seedlings in tropical secondary forests are canopy openness (Denslow, 1987; Tuomela et al., 1996; Jennings et al., 1999; Peña-Claros, 2002) and the quality of light close to the forest floor (Chazdon and Pearcy, 1991; Rijkers et al., 2000; Leakey et al., 2003). In addition, Ramos and del Amo (1992) claimed that the intensity of gap creation has to be matched with species-specific light requirements to achieve sufficient survival and growth rates.

However, the accumulated knowledge about enrichment planting in secondary tropical forests and the per-

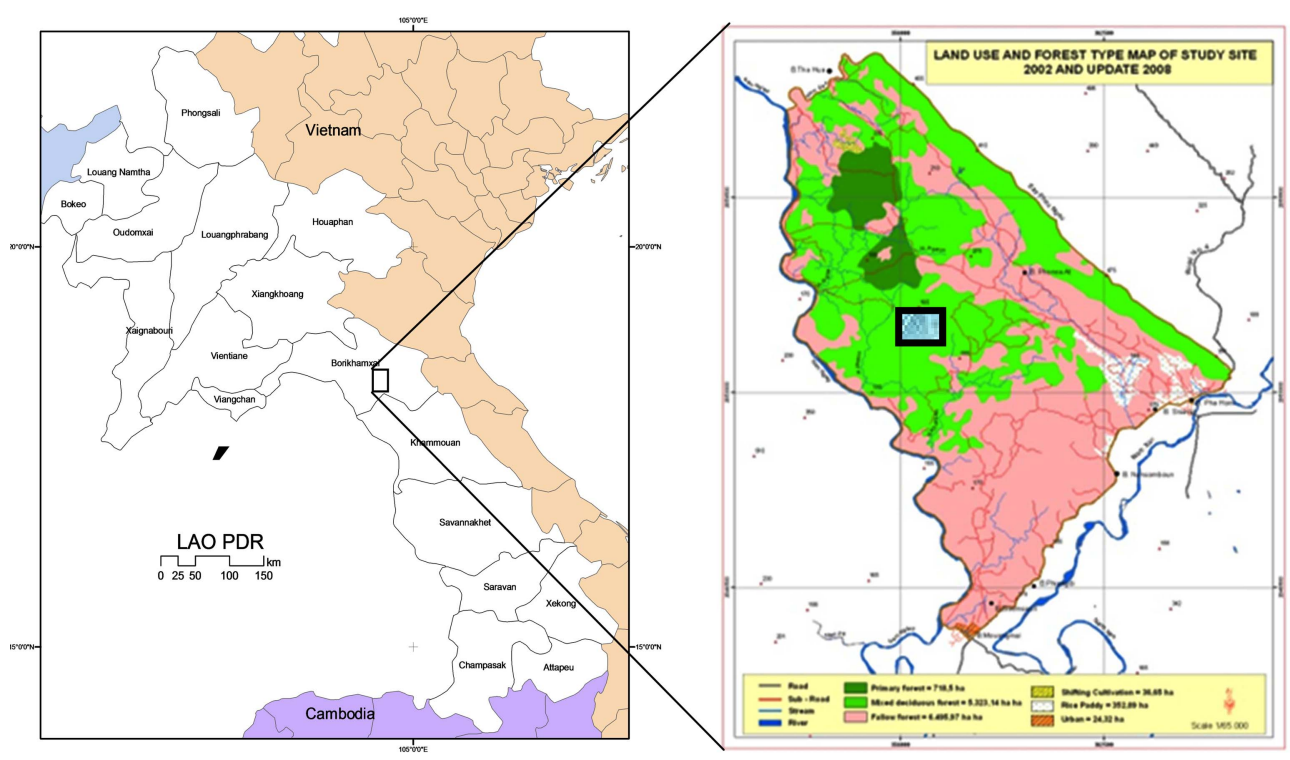

Fig. 1. Location of the study site in Borikhamxay Province, Lao PDR. 
formance of planted species is still limited (Ramos and del Amo, 1992; Ådjers et al., 1995; Kammesheidt, 2002). Therefore, the objectives of this study were to investigate the performance of five native species in enricnhment planting using different canopy opening treatments and to determine the optimal species and silviculture techniques applicable to a logged-over forest in Lao PDR.

\section{MATERIALS AND METHODS}

\subsection{Site description}

The study was conducted in a logged-over lowland mixed deciduous forest in Bolikhan District, Borikhamxay Province, Lao PDR. The area lies between $18^{\circ} 34^{\prime} 35^{\prime \prime}$ $\mathrm{N}$ to $103^{\circ} 41^{\prime} 09^{\prime \prime} \mathrm{E}$ (Fig. 1) and has an average elevation of $164 \mathrm{~m}$ above sea level, with a slope of two to five degrees. The annual rainfall ranged from 2,000 $\mathrm{mm}$ to $2,700 \mathrm{~mm}$ while the temperature ranged from $21.4^{\circ} \mathrm{C}$ to $31.2^{\circ} \mathrm{C}$ for the site. The relative humidity was estimated between 56 and $90 \%$ with average sunlight of 184 hours year ${ }^{-1}$ (Paksan, Borikhamxay Station, 2000 2008).

The study site was originally a lowland mixed deciduous forest. The height was estimated at 26 to $28 \mathrm{~m}$ with 55 to $60 \%$ canopy cover based on the vegetation map from a nationwide reconnaissance survey in 1982 . The forest was covered by dominant commercial species such as Pterocarpus macrocarpus Kurz, Afzelia xylocarpa Craib, Dipterocarpus alatus Roxb. \& GDon, Anisoptera costata Korth., Vatica cinerea King, Hopea odorata Roxb., Dalbergia cochinchinensis Pierre, D. cultrata T.S.Ralph, Schima wallichii Choisy, Cratoxylon spp., and Sindora cochinchinensis Baill.

\subsection{Planting materials}

Five native species, namely Afzelia xylocarpa, Anisoptera costata, Dalbergia cochinchinensis, Dipterocarpus alatus and Hopea odorata, were selected for enrichment planting within the study site. Seedlings were sixmonths-old at the time of planting (June 1, 2002) with an average height of about $50 \mathrm{~cm}$ (AKECOP, 2006).

\subsection{Experimental design}

Enrichment planting by line and gap plantings was conducted using Randomized Complete Block Design with seven replicates. The layout was from East to West and North to South. All trees with diameter at breast height (DBH) of $<5 \mathrm{~cm}$ as saplings and seedlings were cut. The line planting treatments at $2 \mathrm{~m}$ and $3 \mathrm{~m}$ width were used, each with seven lines amounting to a total of 14 lines. The distance between plants was 3 $\mathrm{m}$, and the distance between lines was $20 \mathrm{~m}$ for both treatments. Eleven seedlings for each species were randomly planted in a line. There were a total of 55 seedlings per line and 770 seedlings in total. In the case of gap planting, a size of $14 \mathrm{~m} \times 14 \mathrm{~m}$ was considered with $3 \mathrm{~m}$ distance between plants. Thirty five gaps, with 25 seedlings per plot, were randomly distributed in the experimental area. Overall, 1,645 seedlings were planted occupying a land area of 8.16 ha.

\subsection{Data collection and analysis}

The effects of different canopy openings on survival rate, root collar diameter (RCD), tree height (hereafter described as height), crown height and crown diameter of all seedlings were determined for six years between June 2002 and June 2008. The survival rate was calculated based on the average number of trees per line and gap. RCD, height, crown height and crown diameter growth data were log-transformed prior to analysis.

Mean annual RCD and height increments were also estimated based on existing age of the seedling for each treatment. Means that exhibited significant differences were compared using Duncan's Multiple Range Test (DMRT) at 5\% level of significance. Two way analysis of variance (ANOVA) was performed on the survival

Table 1. Summary of ANOVA for effects of planting treatments (Trt) and species (Sp) on survival rate, root collar diameter (RCD), height, crown height and crown diameter at six years after planting in a logged-over lowland mixed deciduous forest

\begin{tabular}{|c|c|c|c|c|c|c|c|c|c|c|c|}
\hline \multirow{2}{*}{$\begin{array}{l}\text { Sources of } \\
\text { variation }\end{array}$} & \multirow{2}{*}{ df } & \multicolumn{2}{|c|}{ Survival } & \multicolumn{2}{|c|}{$\mathrm{RCD}$} & \multicolumn{2}{|c|}{ Height } & \multicolumn{2}{|c|}{ Crown height } & \multicolumn{2}{|c|}{ Crown diameter } \\
\hline & & $\mathrm{F}$ & $\mathrm{P}$ & F & $\mathrm{P}$ & $\mathrm{F}$ & $\mathrm{P}$ & $\mathrm{F}$ & $\mathrm{P}$ & $\mathrm{F}$ & $\mathrm{P}$ \\
\hline Model & 14 & 4.94 & 0.0001 & 1.89 & 0.0444 & 3.30 & 0.0005 & 5.65 & 0.0001 & 2.78 & 0.0028 \\
\hline Trt & 2 & 1.16 & 0.3198 & 7.16 & 0.0015 & 13.17 & 0.0001 & 11.14 & 0.0001 & 1.52 & 0.2276 \\
\hline $\mathrm{Sp}$ & 4 & 15.97 & 0.0001 & 1.93 & 0.1152 & 3.11 & 0.0209 & 10.39 & 0.0001 & 7.87 & 0.0001 \\
\hline $\operatorname{Trt} \times \mathrm{Sp}$ & 8 & 0.38 & 0.9289 & 0.54 & 0.8195 & 0.93 & 0.4969 & 1.91 & 0.0728 & 0.55 & 0.8111 \\
\hline Error & 65 & & & & & & & & & & \\
\hline
\end{tabular}


Table 2. Mean survival rates of five species at six years after planting in lines and gaps in a logged-over mixed deciduous forest

\begin{tabular}{lcccc}
\hline \hline \multirow{2}{*}{ Species } & \multicolumn{4}{c}{ Planting treatments } \\
\cline { 2 - 5 } & Line 2 m width & Line 3 m width & Gap & Overall mean \\
\hline Hopea odorata & $59.09(9.66) \mathrm{c}$ & $81.82(9.96) \mathrm{a}$ & $73.71(5.37) \mathrm{b}$ & $71.65(8.33)$ \\
Dalbergia cochinchinensis & $62.11(8.81) \mathrm{a}$ & $60.60(8.32) \mathrm{a}$ & $61.14(8.36) \mathrm{a}$ & $61.28(8.49)$ \\
Dipterocarpus alatus & $25.00(9.87) \mathrm{b}$ & $33.33(10.50) \mathrm{a}$ & $30.86(8.67) \mathrm{ab}$ & $29.71(9.68)$ \\
Afzelia xylocarpa & $18.18(3.44) \mathrm{b}$ & $30.30(8.65) \mathrm{ab}$ & $33.71(9.52) \mathrm{a}$ & $29.34(7.20)$ \\
Anisoptera costata & $29.09(5.65) \mathrm{a}$ & $18.18(3.44) \mathrm{b}$ & $28.00(6.35) \mathrm{a}$ & $25.34(5.15)$ \\
\hline
\end{tabular}

Note: Numbers in parentheses indicate standard error; values in a row followed by different letters indicate significant difference at $5 \%$ level of probability using Duncan's Multiple Range Test

rate, $\mathrm{RCD}$, height, crown height and crown diameter in response to treatments and species. All statistical analyses were performed using SAS 9.1.3 (SAS Institute Inc., USA).

\section{RESULTS AND DISCUSSION}

\subsection{Survival rate}

In Lao PDR, the approved standard survival rate for plantation was $70 \%$ of the total planted seedlings (Department of Forestry, 1986). The means of survival rate of planted seedlings showed significant difference among study species $(F=15.97, p=0.0001)$ at six years after planting (Table 1$)$.

Table 2 shows the survival rates of all five species during assessment of the enrichment planting. Hopea odorata and Dalbergia cochinchinensis had higher survival rates among the five species, but the others showed significantly lower rates of below $30 \%$. Survival rates of Dalbergia cochinchinensis showed insignificant differences among the planting treatments and is thus suitable to be planted either through line planting or gap. Hopea odorata, having the highest overall mean survival, showed a significant preference $(p<0.05)$ for $3 \mathrm{~m}$ width line planting in terms of survival rate fol- lowed by gap planting. A similar trend was also observed for Dipterocarpus alatus. On the contrary, survival of Anisoptera costata was the poorest $(p<0.05)$ in the 3 $\mathrm{m}$ width planting treatment. Meanwhile, the survival of Afzelia xylocarpa increased with improved light condition as shown in gap planting.

The suvival of seedlings is much affected by direct results of drought or non-drought stressors, such as herbivores, pathogens and competition exacerbated by drought. During the inventory, we noted that the planting lines were heavily over-shadowed by the crown of surrounding big trees and rampantly growing bamboos compared to gap plantings. The steady closure of canopy from the starting of the second year, due to rapid growth of bamboos and the intermediate canopy trees, had reduced the level of irradiance in both gap and line plantings.

The success of line planting almost depends on light penetration. Insufficient light may cause high survival for shade-tolerant species (Chai and Uderbe, 1977) and light condition is related with line width and stand height as well (Tang and Wadley, 1976). However, there could be other factors influencing the survival of seedlings. According to Adjers et al. (1995), PenaClaros et al. (1995) and Ramos and Amo (1992), line

Table 3. Means of root collar diameter of five species at six years after planting in lines and gaps in a logged-over mixed deciduous forest

\begin{tabular}{lrccc}
\hline \hline \multirow{2}{*}{ Species } & \multicolumn{4}{c}{ Planting treatments } \\
\cline { 2 - 5 } & Line $2 \mathrm{~m}$ width & Line $3 \mathrm{~m}$ width & Gap & Overall mean \\
\hline Hopea odorata & $15.83(0.26) \mathrm{a}$ & $9.00(0.06) \mathrm{b}$ & $14.81(0.20) \mathrm{ab}$ & $13.30(0.17)$ \\
Dalbergia cochinchinensis & $13.61(0.34) \mathrm{a}$ & $6.35(0.07) \mathrm{b}$ & $12.18(0.11) \mathrm{a}$ & $10.79(0.17)$ \\
Dipterocarpus alatus & $14.90(0.40) \mathrm{a}$ & $8.97(0.13) \mathrm{b}$ & $14.35(0.28) \mathrm{a}$ & $13.36(0.27)$ \\
Afzelia xylocarpa & $13.27(0.17) \mathrm{a}$ & $13.43(0.13) \mathrm{a}$ & $10.95(0.21) \mathrm{b}$ & $12.06(0.17)$ \\
Anisoptera costata & $20.74(0.54) \mathrm{a}$ & $6.50(0.08) \mathrm{b}$ & $19.14(0.29) \mathrm{ab}$ & $17.15(0.30)$
\end{tabular}

Note: Numbers in parentheses indicate standard error; values in a row followed by different letters indicate significant difference at $5 \%$ level of probability using Duncan's Multiple Range Test 
direction and width do not affect the survival rate of seedlings. Based on the results of their studies, they suggested that a $6 \mathrm{~m}$ width for line planting is most suitable for a trees growth. Canopy gap between 25 and $54 \%$ is best for height growth while not affecting crown trait and survival. Moura-Costa et al. (1994) and Okimori et al. (2006) confirmed that the main factor affecting survival rate is low annual rainfall.

\subsection{Root collar diameter}

The overall means of RCD were significantly different among treatments $(F=7.16, p=0.0015)$ and species $(F=1.93, p=0.1152)$ as shown in Table 1. All study species showed higher RCD at $2 \mathrm{~m}$ width line planting than the other treatments (Table 3). Anisoptera costata showed the highest overall RCD mean among the study species with the biggest value at $20.74 \mathrm{~mm}$ in $2 \mathrm{~m}$ width line planting followed by gap planting, but with the smallest value in the line planting $3 \mathrm{~m}$ width. Dalbergia cochinchinensis showed the smallest overall $\mathrm{RCD}$ with the lowest value in $2 \mathrm{~m}$ width line planting. In addition, Hopea odorata and Dipterocarpus alatus also showed lower RCD in the $2 \mathrm{~m}$ width line planting. Thus, the results of this study disagree with Adjers et al. (1995) who reported that line width and line direction did not affect the survival and growth of seedlings, but rather horizontal maintenance affected survival and growth of seedlings. Paquettte et al. (2006) suggested that overstorey retention gradient, protection, understorey competition, survival and growth were strongly affected with optimal level of sites (line/strip, gap).

\subsection{Height growth}

Table 1 shows that the overall height means of seedlings were significantlly different among the treatments $(F=13.17, p=0.001)$ and species $(F=3.11, p=0.0209)$. Compared to other species (Table 4), Hopea odorata showed the best height growth followed by Dalbergia cochinchinensis.

All study species showed higher height growth in gap planting than in line planting treatments. This indicated that all seedlings of each species prefer higher light intensity for height growth. However, in line planting treatments, strong damage to the shoot of Afzelia xylocarpa, Anisoptera costata and Dipterocarpus alatus occurred due to limited light intensity. The dipterocarp species in our study also showed differences in height growth in relation to level of light. Hopea odorata appeared to be less shade-tolerant than $A$. costata and D. alatus. In gap planting, optimal gap size of $500 \mathrm{~m}^{2}$ or above has been suggested for better height growth of dipterocarp species (Tuomela et al., 1996). However,

Table 4. Mean of height of five species at six years after planting in lines and gaps in a logged-over mixed deciduous forest

\begin{tabular}{lcccc}
\hline \hline \multirow{2}{*}{ Species } & \multicolumn{4}{c}{ Planting treatments } \\
\cline { 2 - 5 } & Line 2 m width & Line 3 m width & Gap & Overall mean \\
\hline Hopea odorata & $110.33(16.94) \mathrm{ab}$ & $96.53(12.09) \mathrm{b}$ & $139.11(15.00) \mathrm{a}$ & $116.58(14.67)$ \\
Dalbergia cochinchinensis & $80.86(8.84) \mathrm{b}$ & $101.64(10.92) \mathrm{ab}$ & $144.02(12.72) \mathrm{a}$ & $110.69(10.83)$ \\
Dipterocarpus alatus & $47.32(4.36) \mathrm{c}$ & $62.22(3.03) \mathrm{b}$ & $107.31(19.19) \mathrm{a}$ & $80.51(8.86)$ \\
Afzelia xylocarpa & $63.50(8.74) \mathrm{c}$ & $77.44(16.33) \mathrm{b}$ & $110.76(11.76) \mathrm{a}$ & $92.16(12.28)$ \\
Anisoptera costata & $68.23(8.50) \mathrm{b}$ & $62.89(4.60) \mathrm{c}$ & $111.05(19.57) \mathrm{a}$ & $87.15(10.89)$ \\
\hline
\end{tabular}

Note: Numbers in parentheses indicate standard error; values in a row followed by different letters indicate significant difference at $5 \%$ level of probability using Duncan's Multiple Range Test

Table 5. Crown height (Mean \pm standard error) of five species after six years of planting in lines and gaps in logged-over mixed deciduous forest

\begin{tabular}{lclcl}
\hline \hline \multirow{2}{*}{ Species } & \multicolumn{4}{c}{ Planting treatments } \\
\cline { 2 - 5 } & Line $2 \mathrm{~m}$ width & Line $3 \mathrm{~m}$ width & Gap & Overall mean \\
\hline Hopea odorata & $54.62(5.35) \mathrm{b}$ & $49.73(8.65) \mathrm{bc}$ & $83.02(8.24) \mathrm{a}$ & $63.54(7.41)$ \\
Dalbergia cochinchinensis & $41.59(4.41) \mathrm{b}$ & $39.68(5.28) \mathrm{b}$ & $87.40(8.32) \mathrm{a}$ & $58.88(6.00)$ \\
Dipterocarpus alatus & $37.18(8.15) \mathrm{ab}$ & $26.25(3.12) \mathrm{c}$ & $42.41(10.60) \mathrm{a}$ & $36.12(7.29)$ \\
Anisoptera costata & $25.50(6.70) \mathrm{bc}$ & $29.74(3.08) \mathrm{b}$ & $42.91(9.10) \mathrm{a}$ & $34.17(6.29)$ \\
Afzelia xylocarpa & $32.93(9.32) \mathrm{a}$ & $25.46(10.54) \mathrm{b}$ & $26.99(5.81) \mathrm{b}$ & $28.14(8.56)$ \\
\hline
\end{tabular}

Note: Numbers in parentheses indicate standard error; values in a row followed by different letters indicate significant difference at $5 \%$ level of probability using Duncan's Multiple Range Test 
Table 6. Means of crown diameter of five species at six years after planting in lines and gaps in a logged-over mixed deciduous forest

\begin{tabular}{lcccc}
\hline \hline \multirow{2}{*}{\multicolumn{1}{c}{ Species }} & \multicolumn{4}{c}{ Planting treatments } \\
\cline { 2 - 5 } & Line $2 \mathrm{~m}$ width & Line $3 \mathrm{~m}$ width & Gap & Overall mean \\
\hline Hopea odorata & $59.35(5.83) \mathrm{a}$ & $60.08(11.76) \mathrm{a}$ & $51.29(3.65) \mathrm{b}$ & $56.62(8.33)$ \\
Dalbergia cochinchinensis & $54.73(6.49) \mathrm{a}$ & $43.45(6.77) \mathrm{b}$ & $41.44(5.68) \mathrm{b}$ & $45.94(8.49)$ \\
Dipterocarpus alatus & $48.75(4.86) \mathrm{a}$ & $39.68(6.81) \mathrm{b}$ & $48.97(7.51) \mathrm{a}$ & $46.02(9.68)$ \\
Anisoptera costata & $34.88(8.04) \mathrm{ab}$ & $34.28(4.32) \mathrm{ab}$ & $36.26(4.70) \mathrm{a}$ & $35.33(5.15)$ \\
Afzelia xylocarpa & $32.28(2.56) \mathrm{a}$ & $27.19(10.32) \mathrm{b}$ & $6.91(1.39) \mathrm{c}$ & $20.10(7.20)$ \\
\hline
\end{tabular}

Note: Numbers in parentheses indicate standard error; values in a row followed by different letters indicate significant difference at 5\% level of probability using Duncan's Multiple Range Test

for line planting, Pena-Claros et al. (1995), Ramos and Amo (1992), and Adjers et al. (1995) suggested that a 6 to $10 \mathrm{~m}$ width is most suitable for growth.

\subsection{Crown height and diameter}

The overall crown height was significantly different in planting treatments $(F=11.14, p=0.0001)$ and species $(F=10.39, p=0.0001)$ as well. Hopea odorata and Dalbergia cochinchinensis showed higher crown height among the study species. Most species showed higher values in gap planting except Afzelia xylocarpa (Table 5). This implicated that each study species had different adaptations to light conditions, and better light conditions such as the gap is more favorable than other plantation treatments (Tuomela et al., 1996; Pinard et al., 1998).

The overall crown diameter was significantly different among five species $(F=7.87, p=0.0001)$. The overall means of crown diameter showed a decreasing order of Hopea odorata $>$ Dipterocarpus alatus $>$ Dalbergia cochinchinensis $>$ Anisoptera costata $>$ Afzelia xylocarpa (Table 6). The limited growth of crown height and diameter in three planting methods in logged-over forest are strongly affected by light intensity compared to the seedlings planted at open canopy cover areas during the same period (Phengdouang et al., 1994; Phongoudome et al., 2010). A better understanding of ecological traits such as light or shade tolerance for the target species could improve techniques for enrichment planting in secondary forests (Appanah and Weinland, 1993; Kenzo et al., 2008). It is therefore necessary to consider specific species favorable to be planted in light conditions when conducting effective enrichment planting in degraded secondary forests.

\section{CONCLUSION}

The overall highest survival rates were exhibited by
Hopea odorata and Dalbergia cochinchinensis among the five study species in this study. These two species also performed better in terms of height growth and thus, can be used as optimal species for rehabilitation of logged-over and fallow forests in Lao PDR. This study also showed that planting treatments significantly affected seedling growth, regardless of species. Therefore, this implicated that not only the selection of optimal species, but also the selection of planting methods should be thoroughly considered in order to achieve fruitful results in enrichment planting. In addition, constant assessment is recommended in order to verify species suitability and optimum line width or gaps of canopy opening for enrichment planting activities in restoring secondary forest in Lao PDR and other tropical regions.

\section{적 요}

Enrichment planting은 라오스에서 산림복원 프로그 램의 일환으로, 이차림에서 수종의 밀도를 증가시키는 데 흔히 쓰인다. 본 연구는 다섯 종의 자생수종을 대 상으로 임관층을 다양한 방법으로 소개하고 Enrichment planting을 실시하여 라오스에서 개벌 이후 적용할 수 있는 조림방법과 적합한 수종을 조사하였다. 본 연구 결과, 수관층의 높이만 조사수종간 그리고 식재처리간 모두에서 통계적으로 유의한 차이가 나타났다. 묘목의 생존율과 수관층의 직경은 조사수종간에서는 유의한 차 이가 나타났으나, 식재처리간에는 차이가 없었다. 반면 묘목의 근원경과 묘고는 식재처리간에서만 유의한 차 이가 나타났다. 조사수종 중에는 Hopea odorata 와 Dalbergia cochinchinensis 가 다른 수종들에 비해 생 존율과 수고생장 모두 양호한것으로 나타났는데, 이는 이들 수종들이 향후 라오스 산림복원을 위한 Enrichment planting에 적용하기 적합할 것으로 판단된다. 또한 
$2 \mathrm{~m}$ 간격의 line planting은 묘목의 근원경 생장을 촉진 시킬 수 있을 것으로 제안되지만 gap planting과 같이 넓은 간격의 line planting은 묘고생장을 촉진시킨 것 으로 나타났다.

\section{ACKNOWLEDGEMENTS}

This study was carried out with the support of "ASEAN-Korea Environmental Cooperation Project" provided by the Korea Ministry of Foreign Affairs and Trade. The authors sincerely thank the people and staff foresters in Bolikhan District, Borikhamxay Province for their close collaboration during the six years of research.

\section{REFERENCES}

Adjers, G., S. Hadengganan, J. Kuusipalo, K. Nuryanto, and L. Vesa, 1995: Enrichment planting of dipterocarps in logged-over secondary forest: Effect of width, direction and maintenance method of planting line on select Shorea species. Forest Ecology and Management 73, 259270.

AKECOP, 2006: Restoration of Degraded Forest Ecosystem in Southeast Asian Tropical Region. Annual Report 2005-2006. Seoul National University, Korea.

Anderson, M. L., 1951: Spaced group-planting and irregularity of stand-structure. The Empire Forestry Review 30, 328-332.

Anderson, M. L., 1953: Spaced-group planting. Unasylva 7, 55-63.

Appanah, S., and C. T. S. Nair, 1999: FORSPA initiative for forest rehabilitation of tropical forests in the AsiaPacific region. Rehabilitation of Degraded Tropical Forest Ecosystems. (Kobayashi, et al. eds). CIFOR 2-4 November 1999. Bogor, Indonesia, 219-226.

Appanah, S., and G. Weinland, 1993: Planting Quality Timber Trees in Peninsular Malaysia. FRIM, Malaysia, 7891.

Augspurger, C. K., 1984: Light requirements of neo-tropical tree seedlings: A comparative study of growth and survival. Journal of Ecology 72, 777-792.

Chai, D. N. P. and M. P. Uderbe, 1977: The effectiveness of current silvicultural practice in Sabah, Malaysia. Malaysian Forester 40, 27-35.

Chazdon, R. L., and R. W. Pearcy, 1991: The importance of sunflecks for forest understorey plants. Bio. Science 41, 760-766.

Denslow, J. S., 1987: Tropical rain forest gaps and trees species diversity. Annual Review of Ecology and Systematics 18, 431-451.

Denslow, J. S., 1995: Disturbance and diversity in tropical rain forests: The density effect. Journal of Ecological Application 5, 962-968.

Department of Forestry., 1986: Plantation Reguration of Lao PDR. Vientiane, Lao PDR.

Evans, J. and J. W. Turnbull, 2007: Plantation Forestry in the Tropics: The Role, Silviculture, and Use of Planted Forests for Industrial, Socila, Environmental, and Agroforestry Purposes. Oxford University Press. 467pp.

Hartshorn, G. S., 1989: Application of gap theory to tropical forest management: Natural regeneration of strip clear-cuts in Peruvian Amazon. Ecology 70, 567-569.

Inman, F. M., T. R. Wentworth, M. Groom, C. Brownie, and R. Lea, 2007: Using artificial canopy gaps to restore Puerto Rican parrot (Amazona vittata) habitat in tropical timber plantation. Forest Ecology and Mangement 243, 169-177.

Jennings, S. B., N. D. Brown, and D. Sheil, 1999: Assessing forest canopies and understorey illumination, canopy closure, canopy cover and other measures. Forestry $\mathbf{7 2 ,}$ 59-73.

Kammesheidt, L., 2002: Perspectives on secondary forest management in tropical humid Lowland America. Ambio 31, 243-250.

Kenzo, T., R. Yoneda, Y. Matsumoto, M. A. Azani, and M. M. Nik, 2008: Leaf photosynthetic and growth responses on four tropical trees species to different light conditions in degraded tropical secondary forest, Peninsular Malaysia. Japan Agricultural Research Quarterly 42, 299-306.

Kettle, C. J., 2010: Ecological considerations for using dipterocarps for restoration of lowland rainforest in southeast Asia. Biodiversity Conservation DOI 10.1007/s10531009-9772-6.

Kartawinata, K., 1994: The use of secondary forest species in rehabilitation of degraded forest lands. Journal Tropical Forest Sciences 7, 76-86.

Kuuluvainen, T., 2002: Disturbance dynamics in boreal forests: Defining the ecological basis of restoration and management of biodiversity. Silva Fennica 36(1), 5-11.

Lamb, A. F. A., 1969: Artificial regeneration within the humid lowland tropical forest. The Commonwealth Forestry Review 48, 41-53.

Lamb, D., P. D. Erskine, and J. A. Parrotta, 2005: Restoration of degraded tropical forest landscapes. Science $\mathbf{3 1 0}$, 1628-1632.

Lamprecht, H., 1989: Silviculture in the Tropics. Deutsche Gesellschaft fur Techiche Zusammearbeit (GTZ) Germany. 296 pp.

Leakey, A. D. B., M. C. Press, and J. D. Scholes, 2003: High-temperature inhibition of photosynthesis is greater under sunflecks than uniform irradiance in a tropical rain forest tree seedling. Plant Cell and Environment 26, 16811690.

Marod, D., U. Kutintara, H. Tanaka, and T. Nakashizuka, 2004: Effects of drought and fire on seedling survival 
and growth under contrasting light conditions in a seasonal tropical forest. Journal of Vegetation Science 15, 691-700.

Moura-Costa, P., Y. S. Wai, O. C. Lye, A. Ganing, A. Nussbau, and T. Mojium, 1994: Large scale enrichment planting with dipterocarps as an alternative for carbon offsetmethods and preliminary results. Proceeding of $5^{\text {th }}$ Roundtable of Conference on Dipterocarps, ChiangMai, Thailand.

Okimori, Y., J. Kikuchi, and S. Hardiwinoto, 2006: Effect of enrichment planting on restoring the logged-over dipterocarps in a tropical rainforest of central Sumatra. Plantation Technology in Tropical Forest Science (K. Suzuki, K. Ishii,S. Sakurai, and S. Sasaki eds.) Springer, Japan, 231-238.

Oliveira, M. V. N., 2000: Artificial regeneration in gaps and skidding trails after mechanized forest exploitation in acre, Brazil. Forest Ecology and Management 127, 67-76.

Otsamo, R., 2000: Integration of indigenous tree species into fast-growing forest plantations on Imperata cylindrica grasslands in Indonesia - Silvicultural solutions and their ecological and practical implications. Tropical Forestry Reports 21. University of Helsinki, Finland.

Paquette, A., A. Bouchard, and A. Cogliastro, 2006: Survival and growth of under-planted trees: A meta-analysis across four biomes. Ecological Application 16, 1575 1589.

Pariona, W., T. S. Fredericksen, and J. C. Licona, 2003: Natural regeneration and liberation of timber species in logging gap in two Bolivian tropical forests. Forest Ecology and Management 181, 313-322.

Park, A., M. J. Jastiniano, and T. S. Fredericksen, 2005: Natural regeneration and environmental relationships of tree species in logging gaps in Bolivian tropical forest. Forest Ecology and Management 217, 147-157.

Peña-Claros, M., R. G. A. Boot, J. Dorado-Lora, J. and A. Zonta, 2002: Enrichment planting of Bertholletia excels in secondary forest in Bolivian Amazon: Effect of cut- ting line width on survival, growth, and crown traits. Forest Ecology and Management 161, 159-168.

Phongoudome, C., S. Phongdalath, V. Nidtavong, and C. Inthavongsa, 2010: Results of Inventory Data of Six Year-Old and 2-Year-Old Planted Seedlings in Degraded Open Areas in Forestry Research Centre, Laos. Technical Report.

Pinard, M. A., D. W. Davidson, and A. Ganing, 1998: Effect of trenching on grwoth and survival of planted Shorea parvifolia seedlings under pioneer stand in logged-over forest. Journal of Tropical Forest Science 10, 505-515.

Phengdouang, V., K. Khamphanh, K. Phengsengchanh, B. Ramangkoun, P. Lengsouthivong, M. Wallin, and P. Wallis, 1994: Growth Rates of Planted Local Tree Species in Central Lao PDR. Department of Forestry, Vientiane.

Ramos, J. M. and S. del Amo, 1992: Enrichment planting in a tropical secondary forest in Veracruz, Mexico. Forest Ecology and Management 54, 289-304.

Rijkers, T., P. J. de Vries, T. L. Pons, and F. Bongers, 2000: Photosynthetic induction in saplings of three shade-tolerant tree species: Comparing understory and gap habitats in a French Guiana rain forest. Oecologia 125, 331-340.

Romell, E., G. Hallsby, A. Karlsson, and C. Garcia, 2008: Aritificial canopy gaps in a Macaranga spp. dominated secondary tropical rain forest effects on survival and above ground increment of four under-planted dipterocarp species. Forest Ecology and Management 255, 1452-1460.

Tang, H. T. and H. Wadley, 1976: Report on The Survival and Development Survey of Areas Reforested by Line Planting in Selangor. FRIM Research Pamphlet No. 67. Kepong, Malaysia.

Tuomela, K., J. Kuusipalo, L. Vesa, K. Nuryanto, A. P. S. Sagala, and G. Ådjers, 1996: Growth of dipterocarp seedlings in artificial gaps: An experiment in a loggedover rainforest in south Kalimantan, Indonesia. Forest Ecology and Management 81, 95-100.

Wyatt-Smith, J., 1963: Manual of Malayan Silviculture for Inland Forests. Volume 1 Malayan Forest Records No.23. Kuala Lumpur, Malaysia. 